\title{
PENINGKATAN KOMPETENSI MENULIS TEKS EKSPLANASI MELALUI MEDIA PUZZLE KAUSALITAS BERBANTUAN VIDEO
}

\author{
KHABIB BASTARI \\ SMPN 3 Ambarawa Kabupaten Semarang \\ Email : habibahrq@gmail.com
}

\begin{abstract}
ABSTRAK
Hasil pembelajaran menulis teks eksplanasi peserta didik kelas VIII D SMP Negeri 3 Ambarawa semester I tahun pelajaran 2019/2020 masih belum seperti yang diharapkan. Salah satu satu solusi yang diharapkan adalah pembelajaran menggunakan media puzzle kausalitas berbantuan video. Penelitian ini ingin mendeskripsikan proses pelaksanaan pembelajaran menulis menggunakan puzzle kausalitas berbantuan video yang diharapkan mampu meningkatkan kompetensi menulis dan perilaku peserta didik. Teknik pembelajaran ini melatih peserta didik menyusun teks setelah melihat tayangan video dan menyusun urutan kejadian melalui puzzle. Hasil penelitian menunjukkan ketuntasan belajar unjuk kerja menulis teks eksplanasi mengalami kenaikan yang signifikan dari keadaan awal hingga siklus 2. Pada keadaan awal ketuntasan belajar menulis hanya 25,00\% (8 peserta didik) dengan nilai rata-rata $65,82 \%$, meningkat menjadi 90,63\% (29 peserta didik) pada siklus 2 dengan nilai rata-rata $79,10 \%$. Perilaku peserta didik minimal baik pada keadaan awal hanya 43,75\% (14 peserta didik) meningkat menjadi 81,25\% (26 peserta didik), atau meningkat $85,71 \%$. Hasil penelitian menyimpulkan bahwa pembelajaran menulis menggunakan media puzzle kausalitas berbantuan video dapat meningkatkan hasil belajar peserta didik dan meningkatkan sikap/perilaku peserta didik dalam proses pembelajaran.
\end{abstract}

Kata Kunci: kompetensi menulis, teks eksplanasi, puzzle kausalitas, media video.

\section{PENDAHULUAN}

Berdasarkan observasi awal, hasil unjuk kerja menulis teks eksplanasi kelas VIII D pada kompetensi dasar "4.10 Menyajikan informasi dan data dalam bentuk teks eksplanasi secara lisan dan tulis dengan memperhatikan struktur, unsur kebahasaan, atau aspek lisan" menunjukkan hasil belajar yang memprihatinkan sebagaimana tabel 1 berikut.

Tabel 1. Keadaan Awal Hasil Belajar Menulis Teks Eksplanasi

\begin{tabular}{lllllc}
\hline \multirow{2}{*}{ Indikator } & $\begin{array}{l}\text { Jumlah } \\
\text { paragraf }\end{array}$ & $\begin{array}{l}\text { Penyusunan } \\
\text { kalimat }\end{array}$ & $\begin{array}{l}\text { Struktur } \\
\text { teks }\end{array}$ & $\begin{array}{l}\text { Diksi dan } \\
\text { Ejaan }\end{array}$ & Total Nilai \\
\hline Rata-Rata & 3,22 & 2,97 & 2,38 & 2,00 & 66,06 \\
Nilai Tertinggi & 4 & 4 & 4 & 3 & 83,75 \\
Nilai Terendah & 2 & 2 & 1 & 1 & 37,50 \\
\hline \multirow{2}{*}{ Ketuntasan Belajar (\%) } & & & & \multicolumn{2}{c}{$\begin{array}{l}\mathbf{2 5 , 0 0 \%} \text { (8) peserta } \\
\text { didik) }\end{array}$} \\
\hline
\end{tabular}

Tabel 1 tersebut menunjukkan nilai rata-rata menulis hanya 66,06. Nilai tertinggi 83,75 dan nilai terendah 37,50. Sementara ketuntasan belajar peserta didik baru mencapai 25,00\% atau 8 peserta didik dari 32 peserta didik. Hal ini berarti masih 75,00 \% yang belum tuntas belajar. Dilihat dari masing-masing indikator penilaian, nilai rata-rata jumlah paragraf hanya 3,22 , nilai rata-rata penyusunan kalimat 2,97 , nilai rata-rata struktur kalimat 2,34, dan nilai ratarata diksi dan ejaan 2,00. Dengan kata lain dari empat indikator penilaian, hanya indikator jumlah paragraf yang nilai rata-ratanya berkategori baik.

Pada aspek perilaku/sikap peserta didik juga kurang memuaskan sebagaimana tampak tabel 2 berikut. 
Tabel 2. Keadaan Awal perilaku/Sikap Peserta Didik

\begin{tabular}{llcc}
\hline \multirow{2}{*}{ No } & \multicolumn{1}{c}{ Indikator } & \multicolumn{2}{c}{ Keadaan Awal } \\
& & $\sum$ & Persentase (\%) \\
\hline 1. & Perilaku Sangat Baik & 4 & 12,50 \\
2. & Perilaku Baik & 10 & 31,25 \\
3. & Perilaku Cukup Baik & 5 & 15,63 \\
4. & Perilaku Kurang Baik & 13 & 40,63 \\
\hline \multicolumn{5}{c}{ Jumlah } & $\mathbf{3 2}$ \\
\hline
\end{tabular}

Tabel 2 tersebut menunjukkan bahwa dari 32 peserta didik hanya 14 peserta didik yang berperilaku minimal baik, yakni 4 peserta didik $(12,50 \%)$ berperilaku sangat baik dan 10 peserta didik $(31,25 \%)$ berperilaku baik. Sedangkan selebihnya 5 peserta didik atau 15,63\% berpredikat cukup baik, dan 13 peserta didik atau 40,63\% berpredikat kurang baik.

Fakta lapangan tersebut sungguh memprihatinkan mengingat pentingnya kompetensi menulis sebagai salah satu aspek kebahasaan. Menurut pandangan konstruktivisme yang dianut Kurikulum 2013, belajar adalah memproduksi pengetahuan. Muchith (2008) mengatakan bahwa menurut konstruktivisme belajar adalah proses membangun pengetahuan melalui pengalaman nyata di lapangan. Dalam konteks pelajaran bahasa Indonesia, maka di sinilah pentingnya kompetensi menulis. Banyak mengkonsumsi informasi dan pengetahuan dengan banyak membaca dan mendengarkan, tanpa mampu mengungkapkannya dengan berbicara atau menulis, menjadikan hasil belajar kurang bermanfaat.

Dalam menulis teks eksplanasi, peserta didik SMP Negeri 3 Ambarawa mengalami kesulitan dalam pengungkapan ide atau gagasan, penyusunan kalimat, diksi, dan ejaan. Dari aspek guru, selama ini dominan menggunakan model pembelajaran yang kurang menarik bagi peserta didik, yaitu guru didik lebih banyak memberikan pembelajaran teori kaidah-kaidah struktur dan kebahasaan teks eksplanasi. Hanya sedikit waktu untuk menulis. Hasil tulisan peserta didik pun kurang dibahas. Hal ini menimbulkan kejenuhan belajar bagi peserta didik. Selanjutnya, peserta didik merasa berat untuk menulis teks dengan keharusan memenuhi banyak kriteria struktur dan kebahasaannya. Oleh karena itu, peserta didik cenderung menjadi pasif, merasa kesulitan untuk menemukan gagasan awal maupun ketika harus menuliskannya dengan banyak aturan struktur dan kebahasaan teks tersebut.

Permasalahan-permasalahan tersebut memang seharusnya tidak perlu terjadi. Setiap peserta didik diharapkan mampu menulis teks eksplanasi dengan nilai minimal batas ketuntasan. Suasana dalam pembelajaran menulis idealnya mampu mengaktifkan peserta didik, menarik, dan meningkatkan kreativitas peserta didik sehingga pembelajaran benar-benar menghasilkan keterampilan yang dibutuhkan. Oleh karena itu, penelitian ini dilakukan sebagai upaya meningkatkan kompetensi menulis teks eksplanasi melalui media puzzle kausalitas dengan bantuan video. Dengan teknik dan.

Penelitian ini penting dilakukan karena penggunaan puzzle kausalitas dalam menulis teks eksplanasi belum sering dilakukan. Meskipun hal ini mirip dengan penggunaan gambar berseri yang sudah sering terjadi, puzzle diyakini lebih menarik. Menurut Crist (2006) ada beberapa manfaat bermain puzzle. (a) Puzzle adalah cara yang bagus untuk mengasah otak si kecil, melatih sel-selnya, dan bekerja keras. (b) Puzzle dapat melatih koordinasi tangan dan mata anak. Mereka harus mencocokkan keping-keping puzzle dan menyusunnya menjadi satu gambar. Permainan ini membantu anak mengenal bentuk dan ini merupakan langkah penting menuju pengembangan keterampilan membaca. (c) Puzzle dalam bentuk manusia akan melatih nalar mereka. Mereka akan menyimpulkan di mana letak kepala, tangan, kaki dan lain-lain sesuai dengan logika. (d) Puzzle juga dapat melatih kesabaran anak dalam menyelesaikan suatu tantangan. (e) Dengan puzzle anak akan belajar tentang warna dan bentuk. Anak dapat belajar tentang warna-warna dan bentuk yang ada. 
Selanjutnya media video dipilih karena video merupakan sarana komunikasi yang ampuh. Sebagaimana dimaklumi aplikasi video seperti Youtube dan TikTok berkembang pesat. Dengan gambar dan suara, video mampu menyajikan banyak pesan dan manfaat dalam waktu singkat. Apalagi pada era sekarang ini, di mana internet dan media sosial menjadi sarana komunikasi andalan. Menurut Herry (dalam Mangkalan: 2013) media audio visual merupakan kombinasi dari media audio dan media visual atau media pandang dengar. Kombinasi audio dengan visul ini akan lebih menarik dibanding hanya audio atau visual saja.

\section{METODE PENELITIAN}

Penelitian ini merupakan penelitian tindakan kelas dengan teknik analisis deskriptif komparatif terhadap yang diperoleh dari observasi, tes tertulis, dan catatan refleksi. Observasi dilakukan terhadap perilaku/sikap peserta didik selama pembelajaran. Tes tertulis sebagai unjuk kerja kemampuan menulis peserta didik. Sedangkan catatan refleksi dilakukan oleh peserta didik maupun kolaborator peneliti. Penelitian dilakukan dalam dua siklus. Langkah-langkah dalam setiap siklus terdiri atas (1) perencanaan (planning), (2) tindakan (action), (3) observasi (observating), dan (4) refleksi (reflecting).

Pada setiap siklus perencanaan meliputi menyusun RPP, dan lembar kegiatan peserta didik (LKPD), membagi kelompok belajar peserta didik, menyiapkan puzzle, video dan sebagainya. Pada langkah tindakan peserta didik menyaksikan video, menyusun puzzle, menulis teks, dan saling tukar teks untuk disunting, serta dan mengerjakan soal-soal ulangan harian. Selanjutnya, observasi menggunakan lembar observasi berkaitan untuk mengamati perilaku peserta didik, keterlaksanan rencana pembelajaran, dan kendala yang ditemukan selama proses pembelajaran. Sedangkan, refleksi dilakukan bersama peserta didik maupun observer. Indikator keberhasilan penelitian penelitian ini adalah 1) ketuntasan hasil belajar menulis teks eksplanasi peserta didik sekurang-kurangnya $75 \%$ atau atau nilai rata-rata $\geq 75,00,2$ ) perilaku peserta didik minimal baik sekurang-kurangnya $75 \%$.

\section{HASIL DAN PEMBAHASAN}

\section{Siklus 1} berikut.

Hasil belajar peserta didik unjuk kerja menulis teks eksplanasi dapat dilihat pada tabel 3

Tabel 3. Hasil Belajar Menulis pada Siklus 1

\begin{tabular}{|c|c|c|c|c|c|c|}
\hline $\begin{array}{c}\text { Pembelajar } \\
\text { an }\end{array}$ & $\begin{array}{c}\text { Indikator } \\
\text { Nilai }\end{array}$ & $\begin{array}{c}\text { Jumlah } \\
\text { paragraf }\end{array}$ & $\begin{array}{c}\text { Penyusunan } \\
\text { kalimat }\end{array}$ & $\begin{array}{c}\text { Struktur } \\
\text { teks }\end{array}$ & $\begin{array}{c}\text { Diksi dan } \\
\text { Ejaan }\end{array}$ & Total Nilai \\
\hline \multirow{4}{*}{$\begin{array}{l}\text { Keadaan } \\
\text { Awal }\end{array}$} & Rata-Rata & 3,22 & 2,97 & 2,34 & 2,00 & 65,82 \\
\hline & Nilai & 4 & 4 & 3 & 3 & 87,50 \\
\hline & Tertinggi & 2 & 2 & 1 & 1 & 37,50 \\
\hline & \multicolumn{3}{|c|}{ Ketuntasan Belajar } & \multicolumn{3}{|c|}{$25,00 \%$ (8 peserta didik) } \\
\hline \multirow{4}{*}{ Siklus 1} & Rata-Rata & 3,63 & 3,38 & 2,81 & 2,09 & 74,41 \\
\hline & Terendah & 4 & 4 & 4 & 3 & 93,75 \\
\hline & Tertinggi & 2 & 3 & 2 & 2 & 62,50 \\
\hline & \multicolumn{3}{|c|}{ Ketuntasan Belajar } & \multicolumn{3}{|c|}{$65,63 \%$ (21 peserta didik) } \\
\hline \multirow{2}{*}{$\begin{array}{l}\text { Kenaikan } \\
(\%)\end{array}$} & Rata-Rata & 12,73 & 13,80 & 20,09 & 4,50 & 13,05 \\
\hline & \multicolumn{3}{|c|}{ Ketuntasan Belajar } & \multicolumn{3}{|c|}{$162,52 \%$ (selisih 13 peserta didik) } \\
\hline
\end{tabular}

Tabel 3 di atas menunjukkan bahwa rata-rata indikator jumlah paragraf pada keadaan awal hanya 3,22 dan siklus 1 mencapai 3,63; rata-rata indikator penyusunan kalimat pada keadaan awal 2,97 dan siklus 1 mencapai 3,38; rata-rata indikator struktur teks pada keadaan awal 2,34 dan siklus 1 mencapai 2,81; dan rata-rata indikator diksi dan ejaan pada keadaan awal 2,00 dan siklus 1 mencapai 2,09. Bahkan bila dilihat dari jumlah ketuntasan belajar mengalami kenaikan yang cukup signifikan, dari keadaan awal ketuntasan hanya 25,00\% (8 peserta didik) 
pada siklus 1 menjadi 65,63\% (21 peserta didik). Hal ini menunjukkan peningkatan kompetensi menulis teks eksplanasi peserta didik sudah cukup baik, yaitu mencapai 162,52\%.

Dilihat dari jumlah ketuntasan belajar peserta didik secara klasikal pada siklus 1 tersebut yakni 65,63\%, yaitu 21 dari 32 peserta didik, berarti belum memenuhi kriteria. Demikian pula, jika dilihat dari rata-rata nilai unjuk kerja menulis teks eksplanasi yang mencapai 74,41 , berarti juga belum memenuhi kriteria ketuntasan, meskipun kurang sedikit. Oleh karena itu, penelitian ini perlu dilanjutkan pada siklus berikutnya.

Pada aspek perilaku/sikap peserta didik dapat digambarkan melalui tabel 4 berikut.

Tabel 4. Perilaku/Sikap Peserta Didik pada Siklus 1

\begin{tabular}{|c|c|c|c|c|c|c|}
\hline \multirow{2}{*}{ No } & \multirow{2}{*}{ Indikator } & \multicolumn{2}{|c|}{ Keadaan Awal } & \multicolumn{2}{|c|}{ Siklus 1} & \multirow{2}{*}{ Kenaikan $(\%)$} \\
\hline & & $\sum$ & Persentase & $\sum$ & Persentase & \\
\hline 1. & Sangat Baik & 4 & 12,50 & 6 & 18,75 & 50,00 \\
\hline 2. & Baik & 10 & 31,25 & 14 & 43,75 & 40,00 \\
\hline 3. & Cukup & 5 & 15,63 & 8 & 25,00 & 60,00 \\
\hline 4. & Kurang Baik & 13 & 40,63 & 4 & 12,50 & $-69,23$ \\
\hline \multicolumn{2}{|c|}{ Jumlah } & 32 & & 32 & & \\
\hline
\end{tabular}

Berdasarkan tabel 4 tersebut, pada keadaan awal peserta didik yang berpredikat berperilaku sangat baik hanya 4 peserta didik $(12,50 \%)$, yang berpredikat berperilaku baik 10 peserta didik $(31,25 \%)$, yang berpredikat cukup baik 5 peserta didik $(15,63 \%)$, dan berpredikat kurang baik 13 peserta didik (40,63\%). Sedangkan pada siklus 1 peserta didik yang berpredikat berperilaku sangat baik 6 peserta didik $(18,75 \%)$, yang berpredikat berperilaku baik 14 peserta didik $43,75 \%)$, yang berpredikat cukup baik 8 peserta didik $(25,50 \%)$, dan berpredikat kurang baik 4 peserta didik (12,50\%). Hasil tersebut menunjukkan perilaku peserta didik dengan predikat sangat baik mengalami kenaikan, yaitu dari empat peserta didik menjadi enam peserta didik atau mengalami kenaikan sebesar 50\%. Sedangkan peserta didik berpredikat kurang baik mengalami penurunan yang signifikan, yaitu dari 13 peserta didik menjadi 4 peserta didik atau mengalami penurunan sebesar $-69,23 \%$.

Ada beberapa hasil refleksi peserta didik. 1) Peserta didik termotivasi bekerja sama dalam kelompok, menyenangkan, dan menghibur; sehingga lebih mudah dalam menulis teks eksplanasi. 2) Peserta didik merasa lebih mudah mengingat dan memahami kausalitas dan urutan terjadinya peristiwa alam. 3) Kesulitan yang dihadapi peserta didik terutama adalah pada penerapan ejaan, penggunaan diksi, dan kesulitan membagi-bagi kalimat. 4) Saran yang diberikan peserta didik adalah agar gambar supaya diperjelas dan jumlah gambar dalam puzzle ditambah.

Sedangkan, data yang diperoleh berdasarkan hasil refleksi observer adalah sebagai berikut. 1) Proses pembelajaran sudah cukup baik karena sudah sesuai dengan rencana yang disusun. 2) Guru sebagai peneliti menunjukkan kinerja yang cukup baik karena aktif dalam kegiatan belajar mengajar. 3) Sebagian besar peserta didik sudah menunjukkan perilaku yang cukup baik, aktif dalam kegiatan kelompok. Hanya beberapa peserta didik yang kurang aktif dalam kegiatan kelompok, kurang konsentrasi, dan masih ada yang ngobrol di luar materi pembelajaran. 4) Saran yang diberikan adalah agar jumlah gambar pada puzzle bisa ditambah dan jumlah anggota kelompok dikurangi. 
Siklus 2

Hasil belajar menulis teks eksplanasi pada siklus 2 dapat dilihat pada tabel 5 berikut.

Tabel 5. Hasil Belajar Menulis Teks Eksplanasi pada Siklus 2

\begin{tabular}{|c|c|c|c|c|c|c|}
\hline Pembelajaran & $\begin{array}{l}\text { Indikator } \\
\text { Nilai }\end{array}$ & $\begin{array}{l}\text { Jumlah } \\
\text { paragraf }\end{array}$ & $\begin{array}{l}\text { Penyusunan } \\
\text { kalimat }\end{array}$ & $\begin{array}{l}\text { Struktur } \\
\text { Teks }\end{array}$ & $\begin{array}{c}\text { Diksi } \\
\text { dan } \\
\text { Ejaan }\end{array}$ & Total Nilai \\
\hline \multirow{4}{*}{ Siklus 1} & Rata-Rata & 3,63 & 3,38 & 2,81 & 2,09 & 74,41 \\
\hline & Tertinggi & 4 & 4 & 4 & 3 & 93,75 \\
\hline & Terendah & 2 & 3 & 2 & 2 & 62,50 \\
\hline & \multicolumn{3}{|c|}{ Ketuntasan Belajar (\%) } & \multicolumn{3}{|c|}{$65,63 \%$ ( 21 peserta didik) } \\
\hline \multirow{4}{*}{ Siklus 2} & Rata-Rata & 3,69 & 3,38 & 3,03 & 2,56 & 79,10 \\
\hline & Tertinggi & 4 & 4 & 4 & 4 & 93,75 \\
\hline & Terendah & 3 & 3 & 2 & 2 & 68,75 \\
\hline & \multicolumn{3}{|c|}{ Ketuntasan Belajar (\%) } & \multicolumn{3}{|c|}{$90,63 \%$ (29 peserta didik) } \\
\hline \multirow{2}{*}{ Kenaikan (\%) } & Rata-Rata & 1,65 & $\mathbf{0}$ & $\mathbf{7 , 8 3}$ & 22,49 & 34,01 \\
\hline & \multicolumn{3}{|c|}{ Ketuntasan Belajar (\%) } & \multicolumn{3}{|c|}{$38,09 \%$ (selisih 8 peserta didik) } \\
\hline
\end{tabular}

Tabel 5 tersebut menunjukkan bahwa hasil unjuk kerja menulis teks eksplanasi secara umum mengalami peningkatan. Rata-rata indikator jumlah paragraf pada siklus 1 mencapai 3,63 dan siklus 2 mencapai 3,69; rata-rata indikator penyusunan kalimat pada siklus 1 adalah 3,38 dan siklus 2 tetap 3,38; rata-rata indikator struktur teks pada siklus 1 adalah 2,81 dan siklus 2 mencapai 3,03; dan rata-rata indikator diksi dan ejaan pada siklus 1 adalah 2,09 dan siklus 2 mencapai 2,56. Dilihat dari jumlah ketuntasan belajar, pada siklus 1 hanya 65,63\% (21 peserta didik) pada siklus 2 menjadi 90,63\% (29 peserta didik). Hal ini menunjukkan kompetensi menulis teks eksplanasi peserta didik sudah mengalami kenaikan cukup signifikan, yaitu mencapai $34,01 \%$. Tidak adanya peningkatan pada indikator penyusunan kalimat ini dikarenaka guru lebih fokus untuk perbaikan pada indikator ejaan.

Hasil observasi tentang perilaku/sikap peserta didik dari kondisi awal hingga siklus 2 tampak pada gambar 1 berikut.

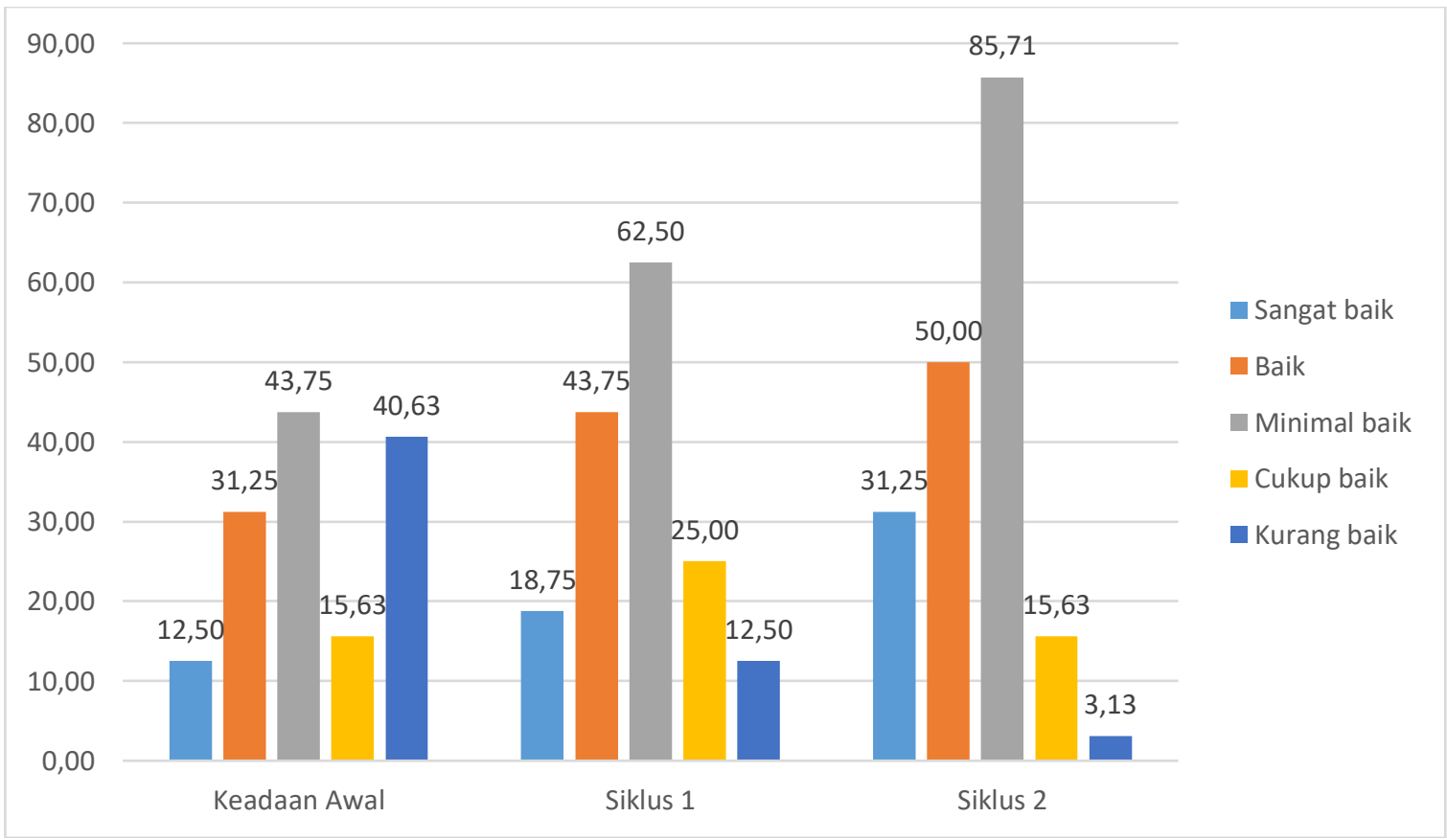

Gambar 1. Perubahan Perilaku/Sikap Peserta Didik 
Gambar 1 tersebut menunjukkan peningkatan perilaku baik dan sangat baik dari kondisi awal sampai dengan siklus 2. Pada kondisi awal yang berkategori sangat baik hanya $12,50 \%$ (4 peserta didik), yang berkategori sangat baik pada siklus 1 mencapai 18,75\% (6 peserta didik), dan siklus 2 yang berkategori sangat baik $31,25 \%$ (10 peserta didik). Perubahan perilaku peserta didik yang berkategori baik juga mengalami peningkatan. Pada kondisi awal yang berkategori baik adalah $31,25 \%$ (10 peserta didik), pada siklus 1 meningkat menjadi 43,75\% (14 peserta didik), dan siklus 2 menjadi 50,00\% (16 peserta didik).

Data tersebut menunjukkan bahwa peserta didik yang berperilaku minimal baik meningkat dari kondisi awal ke siklus 2. Pada konsisi awal peserta berperilaku minimal baik hanya 43,75\% (14 peserta didik), meningkat pada siklus 1 menjadi 62,50\% (20 peserta didik), dan meningkat lagi pada siklus 2 menjadi 85,71\% (26 peserta didik).

Sedangan, perilaku peserta didik yang berkategori cukup baik mengalami peningkatan pada siklus 1 dibanding pada keadaan awal, tetapi menurun pada siklus 2 dibanding pada siklus 1. Perilaku cukup baik pada keadaan awal 15,63\% (5 peserta didik), pada siklus 1 sebesar $18,18 \%$ (6 peserta didik), dan pada siklus 2 kembali 15,63\% (5 peserta didik). Adapun perilaku peserta didik yang berkategori kurang baik perentasenya terus menurun dari siklus 1 hingga siklus 2. Pada keadaan awal yang berperilaku kurang baik sebesar 40,63\% (13 peserta didik), siklus 1 menjadi 12,50\% (4 peserta didik), dan siklus 2 menjadi 3,13\% (1 peserta didik).

Berdasarkan hasil refleksi peserta didik diperoleh beberapa data berikut. 1) Hampir semua peserta didik merasa senang dengan pembelajaran yang dilakukan. 2) Kesulitan berkonsentrasi dan kurang ingat sebab - akibat keseluruhan kejadian di dalam video dan bisa teratasi dengan adanya puzzle. 3) Saran yang diberikan adalah agar gambar pada puzzle diperjelas dan agar bingkai puzzle jangan longgar.

Data yang diperoleh berdasarkan hasil refleksi observer adalah sebagai berikut. 1) Proses pembelajaran sudah sesuai dengan rencana yang disusun dengan memperhatikan kendala yang dihadapi pada sikuls 1 sudah teratasi. 2) Gambar puzzle sudah diperbanyak dan jumlah anggota kelompok sudah diperkecil. 3) Peserta didik maupun peneliti tampak aktif di dalam kegiatan pembelajaran. 4) Kelebihan pembelajaran menulis teks eksplanasi menggunakan media ideo dan puzzle kausalitas lebih menyenangkan dan peserta didik lebih mudah mengembangkan rangkaian kejadian menjadi teks eksplanasi.

\section{Pembahasan}

Pada siklus 1 pembelajaran sudah cukup baik tetapi masih terdapat beberapa kekurangan. 1) Guru belum optimal dalam membimbing dan memfasilitasi peserta didik yang mengalami kesulitan dalam menulis teks eksplanasi, terutama masalah penulisan diksi dan ejaan. Hal ini menyebabkan hasil menulis teks eksplanasi pada indikator diksi dan ejaan kurang maksimal. 2) Jumlah anggota tiap kelompok masih terlalu banyak (5-6 orang) sehingga beberapa peserta didik kurang serius dan tampak pasif dalam kerja kelompok (menyusun puzzle), di lain pihak ada peserta didik yang dominan. 3) Jumlah gambar pada puzzle hanya ada empat gambar sehingga hanya menggambarkan urutan sebab-akibat dan belum menggambarkan struktur teks.

Kekurangan tersebut disebabkan oleh hal-hal. 1) Kesulitan peserta didik dalam penulisan diksi dan ejaan karena peserta didik tidak terbiasa menulis dengan ejaan yang benar dan kurangnya kosa kata yang dimiliki peserta didik. 2) Jumlah anggota kelompok terlalu banyak sehingga ada peserta yang kurang aktif dan ada yang terlalu dominan. 3) Jumlah gambar pada puzzle yang hanya 4 menyebabkan peserta didik kurang bisa mengembangkan tulisannya walaupun sudah ditayangkan videonya. 4) Ada peserta didik yang dari keluarga broken home dan pernah tinggal kelas yang menyebabkan guru kesulitan meningkatkan motivasi belajarnya.

Sementara itu ada beberapa hal positif dari keberhasilan belajar pada siklus 1. 1) Peserta didik menunjukkan interaksi yang positif terhadap media pembelajaran, mereka tampak lebih senang dan antusias dalam mengikuti pembelajaran. 2) Dengan adanya penayangan video dan puzzle, memudahkan peserta didik mengingat kausalitas dan urutan kejadian sehingga merasa 
lebih mudah ketika menulis menulis teks eksplanasi. 3) Secara umum peserta didik tampak lebih aktif dan antusias dalam pembelajaran. Hal-hal positif ini berpengaruh terhadap peningkatan ketuntasan hasil belajar dan perubahan perilaku peserta didik ke arah yang lebih baik.

Sementara proses pembelajaran pada siklus 2 juga meningkat lebih baik dibandingkan dengan silkus 1, baik dalam kinerja guru sebagai peneliti maupun proses pembelajaran. Hal ini telah sesuai dengan yang direncanakan peneliti. Guru mampu menjadi fasilitator dalam membimbing peserta didik dalam pembelajaran. Permasalahan-permasalahan yang dihadapi pada siklus 1 sudah dapat diselesaikan, yaitu gambar puzzle sudah diperbanyak (pada siklus 1 hanya 4 gambar sudah menggambarkan urutan kausalitas, tetapi belum menggambarkan struktur teks; pada siklus 2 ada 9 gambar, sudah mengandung urutan kausalitas dan menggambarkan struktur teks) Jumlah anggota kelompok sudah diperkecil (pada siklus 1 anggota per kelompok 5-6 peserta didik, siklus 2 anggota per kelompok 3-4 peserta didik).

Berdasarkan data hasil penelitian yakni, 1) ketuntasan belajar menulis teks eksplanasi, kondisi awal 25\% (8 peserta didik), pada siklus $165,63 \%$ (21 peserta didik), dan pada siklus 2 menjadi 90,63\% (29 peserta didik); 2) perilaku peserta didik minimal baik, hanya 43,75\% (14 peserta didik), pada siklus 1 menjadi 62,50\% (20 peserta didik), dan meningkat lagi pada siklus 2 menjadi 85,71\% (26 peserta didik), maka dapat dipahami bahwa hasil penelitian telah mencapai indikator keberhasilan.

Hasil penelitian ini relevan dengan beberapa penelitian sebelumnya di antaranya Lela Tri Wahyuningtias (2015) yang menggunakan media video; Novita Andyani, Kundharu Saddhono, Yant Mujyanto (2016), menggunakan media audiovisul; Nofi Salfera (2017), menggunakan media gambar berseri; dan Pranata (2018) menggunakan model pisture and picture. Semua penelitian sebelumnya tersebut menyebutkan peningkatan kompetensi menulis teks eksplanasi melalui media yang digunakan.

\section{KESIMPULAN}

Berdasarkan pembahasan hasil penelitian "upaya meningkatkan kompetensi menulis teks eksplanasi melalui media puzzle kausalitas berbasis video pada peserta didik kelas VIII di SMP Negeri 3 Ambarawa semester 1 tahun pelajaran 2019/2020" dapat disimpulkan bahwa pembelajaran melalui media puzzle kausalitas berbantuan video dapat meningkatkan kemampuan menulis dan perilaku peserta didik. 1) Ketuntasan belajar menulis teks eksplanasi, kondisi awal hanya 25\% (8 peserta didik), menjadi 65,63\% (21 peserta didik) pada siklus 1, dan 90,63\% (29 peserta didik) pada siklus 2. 2) Perilaku peserta didik minimal baik, pada keadaan awal hanya $43,75 \%$ (14 peserta didik), pada siklus 1 menjadi $62,50 \%$ (20 peserta didik), dan pada siklus 2 menjadi $85,71 \%$ (26 peserta didik).

\section{DAFTAR PUSTAKA}

Andyani, N. at. al. (2016). Jurnal "Peningkatan Kemampuan Menulis Teks Eksplanasi dengan Menggunakan Media Media Audiovisual pada Siswa Sekolah Menengah Pertama”. https://media.neliti.com/media/publications/

Mangkalan, D. (2013). Artikel "Pengertian Media Pembelajaran Menurut Ahli + Referensi". http://www.bimbingan.org/definisi-film.htm.

Muchith, M. S. (2008). Pembelajaran Kontekstual. Semarang: Rasail Media Group.

Pranata, B. A. (2018). Pembelajaran Menyajikan Data dan Informasi Dalam Bentuk Teks Eksplanasi Dengan Memperhatikan Struktur dan Kaidah Kebahasaan Menggunakan Model Picture And Picture pada Siswa Kelas VIII SMP Negeri 2 Lembang Tahun Pelajaran 2017/2018. Skripsi (S1) thesis, FKIP UNPAS. http://repository.unpas.ac.id/41533/

Sagami, G. C. (2012). Skripsi "Keefektifan Media Komik Tanpa Teks dalam Pembelajaran Menulis teks eksplanasi pada Siswa Kelas VII SMP Negeri 1 Wates". Yogyakarta: Universitas Negeri Yogyakarta. 
Salfera, N. (2017). Jurnal "Meningkatkan Kemampuan Menulis Teks Eksplanasi dengan Menggunakan Media Gambar Berseri pada Siswa Kelas VII". https://jurnal.iicet.org/index.php/j-edu/article/view/95.

Wahyuningtias, L. T. (2015). Jurnal "Peningkatan Keterampilan Menyusun Teks Eksplanasi dengan Model pembelajaran Berbasis Masalah Menggunakan media video peristiwa alam pada Peserta Didik Kelas VII $F \quad$ SMP $N \quad 1$ Blora". https://lib.unnes.ac.id/22206/1/2101411019-s.pdf . 